\title{
THE INFLUENCE OF SOIL COVER ON LAKES IN NORTHERN ESTONIA
}

\author{
ANDRES TÕNISSON
}

Estonian Meteorological and Hydrological Institute, Rävala 8, Tallinn 10143 Estonia,

Phone: (372) 6203853, (372) 6203850; Fax: (372) 6203696 E-mail: leetva@online.ee

ABSTRACT. During the summers of 1997-98, in a pine-forested sloping watershed, soil water from calcareous and sandy soil horizons was collected on nine occasions. In total 8 lysimeters were used. The amount of water percolating through sandy test site was up to three times smaller than that through calcareous test site. The influence of soil cover on the percolating water is also significant. The sandy site is able to produce even more diluted water than that originally coming from precipitation. Concentrations of TOC are varying more than the conductivity values. The concentration of TOC on the calcareous site was 2...2,5 times higher than that on the sandy site. The total emission of TOC from the transitional humus-rich test site could be higher by up to 20 times as compared with sandy site.

Seepage lake, catchment influence, soil cover, carbon leakage, lysimetry

\section{Introduction}

The content of substances and ions in a soil solution reflects the atmospheric input and the main transformation processes in the soil. Information about the content of substances in soil water is consequently of great importance in the assessment of the soil bio-geochemical status and the potential for leaching of substances from the soil to the groundwater and via this to the lake. The recording of gravitational water is crucial to the understanding of both the nutrient release and formation of water quality in neighbourhood lakes.

Since 1993 two North-Estonian small seepage lakes, an oligotrophic and a mesohumic one, have been the objects of ecological study. Closely located lakes, underlain by similar glacial deposits and receiving similar levels of deposition, were found to have different contents of inorganic and organic matter. The aim of this paper is to present some basic data on the values of electrolytic conductivity and total organic carbon (TOC) in subsoil water circulating within these small catchments (24 ha and $11 \mathrm{ha}$ ). Water in adjacent seepage lakes is strongly affected by the infiltration capacity of the drainage area and the washed-in materials.

\section{Materials and methods}

The main site for this investigation is the watershed of Lake Umerikjärv $\left(59^{\circ} 24^{\prime} \mathrm{N}, 25^{\circ} 41^{\prime} \mathrm{E}, \mathrm{S}=1,6 \mathrm{ha}\right)$. The watershed of Lake Paukjärv ( $\left.\mathrm{S}=8,6 \mathrm{ha}\right)$ is only 400 meters away. Both lakes have similar mean depths - 5 meters. Sandy shores form respectively $45 \%$ and $80 \%$ of the total shore length of the two lakes. Fluvio- and limnoglacial deposits form the parent material for the soils. Considering the soil formation process, the parent material can be characterised by 1) quick infiltration of water; 2) low field moisture capacity; 3) low concentration of available nutrients; 4) very thin $(0-3 \mathrm{~cm})$ humus horizon. Two main soil types occur on this area: thin sandy podzol (P) and calcaric luvisol (C), which associates with fluvioglacial esker. The first mentioned type has two subtypes: one is a sandy podzol without humus horizon (P-S) 
and the second one is a soil with small humus horizon (P-H). Respective vegetationtypes on the test sites are pine-forest with Calluna vulgaris on the first storey (P) and pine-spruce forest with Vaccinium myrtillus (C). The description of research area and previously conducted investigations are given in Tõnisson (1996).

Soil water (percolation water) was collected four times between July and November 1997 and five times between May and November 1998 using plate lysimeters (8), installed in depths of $15 \mathrm{~cm}$ (eluvial horizon) and $30 \mathrm{~cm}$ (illuvial horizon) in four test sites. Lysimeters were installed close to the lakes, the distance from lakeshore ranges from 5 to 20 meters. Similar free filtration lysimeters are used in two Estonian Baltic Integrated Monitoring sites. Mr. Martin Voll developed lysimeters and they are registered as an invention in the Estonian Patent Office. Among the lysimeters seven are gauging the water seeping downwards and one is gauging the water seeping horizontally downslope. The description of particular lysimeters sites follows.

Two observed summers were different concerning the rainfall. The mean monthly rainfall in 1997 was around $55 \mathrm{~mm}$ and in 1998 around $95 \mathrm{~mm}$ on the open ground. The amount of stand precipitation is supposed to be somehow $25-30 \%$ lower than in an open area.

Table 1

Lysimeters and their location

\begin{tabular}{|l|c|c|l|c|c|}
\hline Number & Sign & $\begin{array}{c}\text { Depth } \\
(\mathrm{cm})\end{array}$ & $\begin{array}{l}\text { Slope and } \\
\text { exposure }\end{array}$ & Soil & $\begin{array}{c}\text { Mean discharge } \\
\text { (mm per month) }\end{array}$ \\
\hline 1. & P-15 & 15 & $30^{\circ} \mathrm{SW}$ & $\mathrm{C}$ & 33 \\
\hline 2. & U-15 & 15 & $35^{\circ} \mathrm{E}$ & $\mathrm{C}$ & 35 \\
\hline 3. & U-30 & 30 & $35^{\circ} \mathrm{E}$ & $\mathrm{C}$ & 29 \\
\hline 4. & U-H(horizontal) & $10-35$ & $35^{\circ} \mathrm{E}$ & $\mathrm{C}$ & 12 \\
\hline 5. & O-15 & 15 & $10^{\circ} \mathrm{N}$ & P-H & 55 \\
\hline 6. & O-30 & 30 & $10^{\circ} \mathrm{N}$ & P-H & 53 \\
\hline 7. & L-15 & 15 & $10^{\circ} \mathrm{W}$ & P-S & 16 \\
\hline 8. & E-15 & 15 & $5^{\circ} \mathrm{SW}$ & P-S & 35 \\
\hline
\end{tabular}

Water was collected from gauges once the precipitation amount for the observed period exceeded $60 \mathrm{~mm}$. Electrolytic conductivity was determined in situ using the Dissolved Solids Tester DiST 3 ATC and TOC was analysed on an automatic TOC analyser DC80 in Tallinn Water Treatment Plant.

\section{Results and discussion}

The seasonal curve of subsoil water is strongly dependent on precipitation curve. In the case of the forested catchment the amount of precipitation that is delivered to the land surface (effective rainfall) is estimated to be $70 \%$ of the incoming precipitation. Furtber percolation rates depend on local conditions. Particular lysimeters have different discharge (Fig. 1).

On the top $30 \mathrm{~cm}$ layer, most of subsoil water $(30 \ldots 90 \%$ from rainfall) percolates vertically downwards. Mean amount of subsoil water percolating horizontally exceeds up to $20 \%$ from mean rainfall. Percolation of rainwater is the 
second probable source (via groundwater supply) of lake supply after direct rainfall in the case of seepage lakes. During the observed period lakes were supplied with subsoil water mostly by the transitional depression valley $(\mathrm{P}-\mathrm{H})$ and esker shore $(\mathrm{C})$.

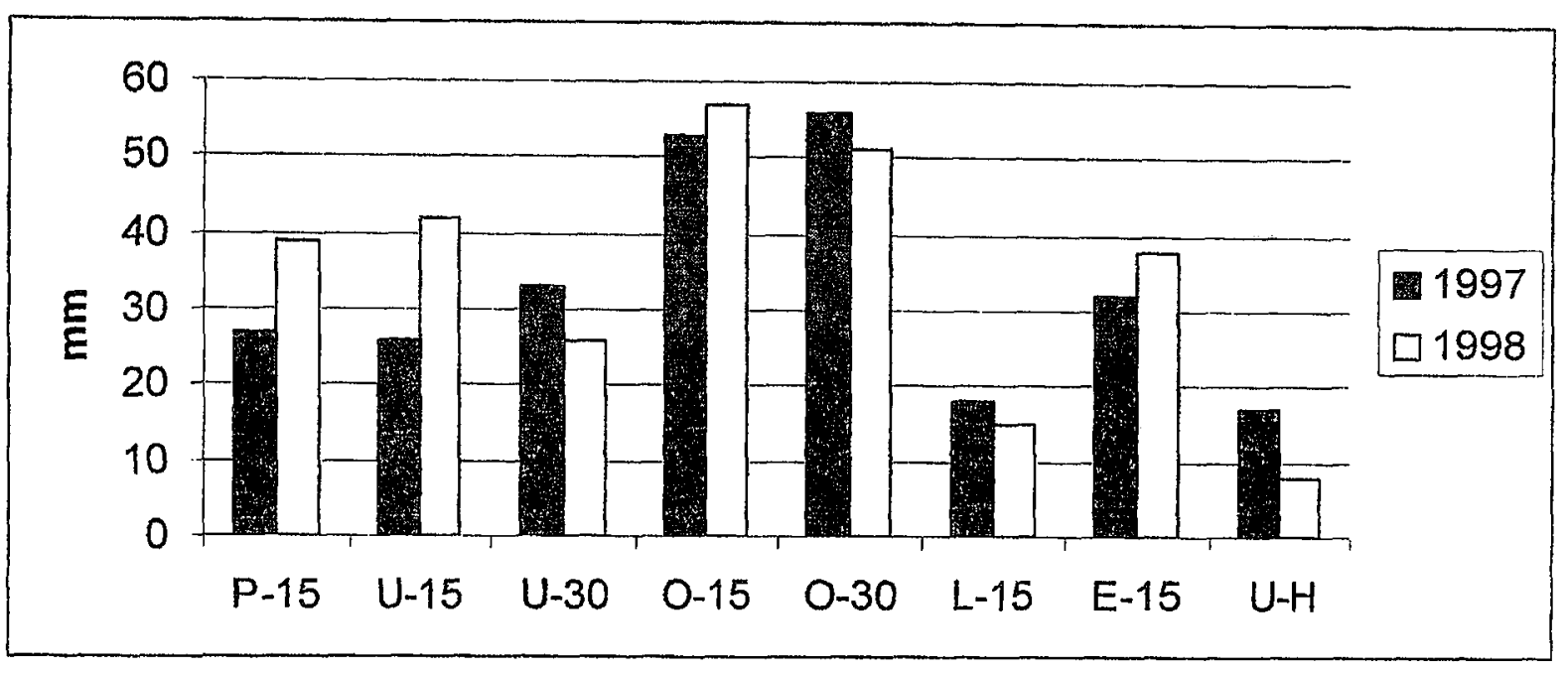

Fig. 1. The mean monthly (May-October) discharge ( $\mathrm{mm}$ ) in lysimeters

The chemical results obtained on the lakes and surrounding subsoil waters tend to show that the exchange of the water between lakes and watershed takes place slowly. The roughly estimated water retention period in these lakes ranges from 6 to 8 years. This is definitely indicated by the marked differences in the electrolytic conductivity values of the lake waters $\left(k_{20}=15 . .50 \mu \mathrm{S} \mathrm{cm}^{-1}\right)$ and that of surrounding subsoil waters $\left(k_{20}=10 \ldots 170 \mu \mathrm{S} \mathrm{cm}^{-1}\right)$.

The enrichment of precipitation is rather stable down to the observed depth $(30 \mathrm{~cm})$. The sandy podzsol (P-S) is sometimes able to produce even more diluted water than that originally coming from precipitation. The single horizontal lysimeter on the esker shore was somewhat more enriched, as compared with vertical lysimeters. The seasonal pattern of enrichment of subsurface water remained unclear everywhere.

The lysimeter recordings indicate that significant differences in water circulation between different lakeshores can be found. Partly these variations are determined by the variability of evapotranspiration conditions. The last are derived from slope exposure, exposure to winds and sunlight as well from plant cover and ground permeability. Large spatial heterogeneity of the soil material of an esker formation (C) may also cause the great variation of percolation rates. Sandy shores $(\mathrm{P}-\mathrm{S})$ form respectively $80 \%$ and $45 \%$ of the total shore length of the two lakes. The first one of them (Lake Paukjärv) seems to be therefore more diluted because the sandy podzol is poorer in carbonates and other readily soluble constituents.

It is, however, evident that the lysimeter recordings cannot determine the exact infiltration amounts nor water and matter entering a lake. So far it remains impossible to gauge the subsurface water-flow immediately on the contact surface. Therefore this discussion is focuses on the probable inflow. Yet the hydrologic budgets of small seepage lakes seem to be dominated overwhelmingly by direct precipitation on the lake surface. Percolation of subsoil water into lakes is highly seasonal, occurring mainly in spring and autumn. 
Concentrations of organic matter (after TOC) in subsoil water vary more $(15 \ldots 160 \mathrm{ppm})$ than concentrations of mineral substances. In the lakes the TOC content ranges from $8 \ldots 12 \mathrm{ppm}$. Oligotrophic Lake Paukjärv is obviously poorer from organic matter than mesohumic Lake Umerikjärv. In the shore belt, the TOC content varies considerably in subsurface water (Fig. 2). The concentrations of TOC increase steadily during summer and autumn in esker soils $(\mathrm{C})$ and in transitional depression valley $(\mathrm{P}$ $\mathrm{H}$ ), where intensive decomposition processes take place. At the same time the TOC content in poor podzols (L) remains stable. Probably the greatest enrichment of lakes with organic matter takes place before the ground freezes.

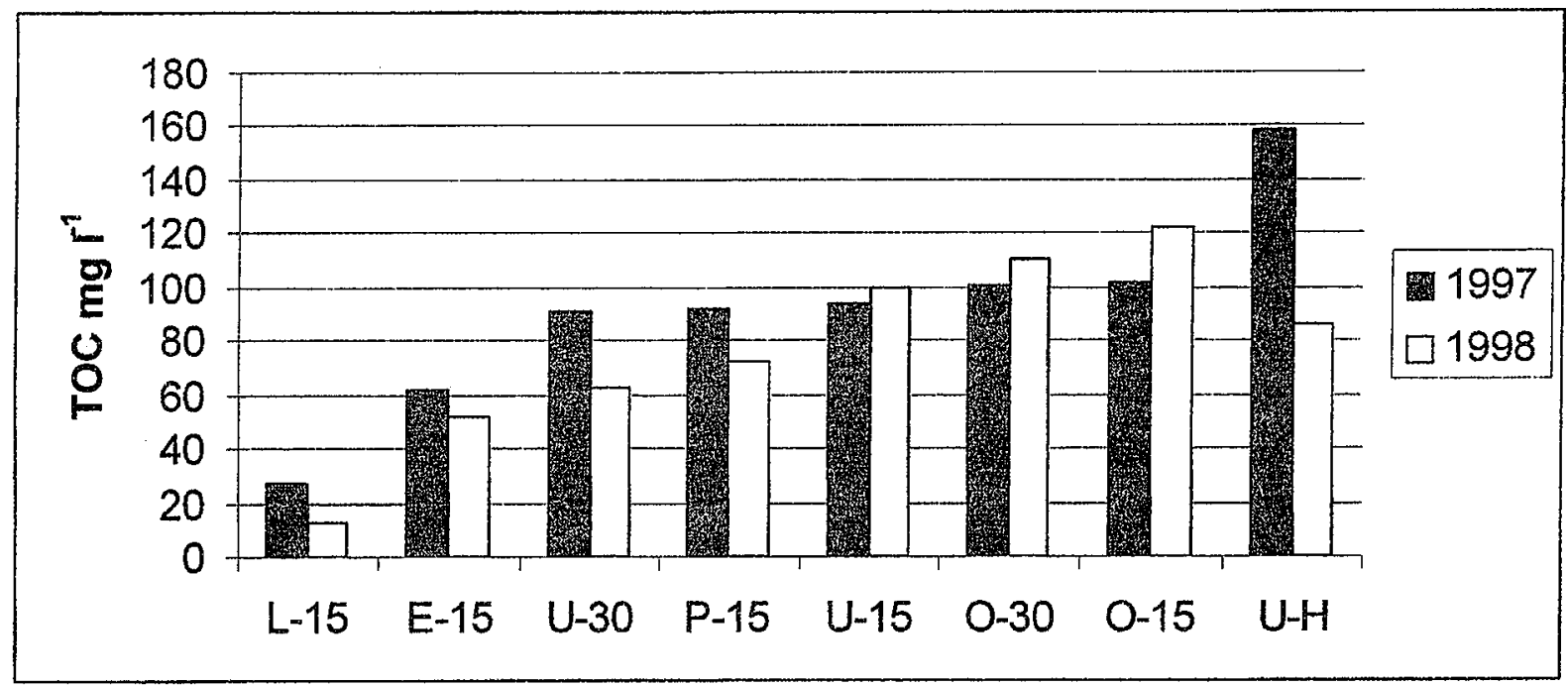

Fig. 2. Recordings of TOC in subsoil water

The washout rate of organic matter differs significantly within the catchment. It has been indicated by many authors that the wash-out rate of organic matter depends directly on rainfall intensity. This statement was proved on the basis of single lysimeters (Fig. 3). As we see further, this is not valid expectation when we compare longer period.

With depth the TOC content in subsoil water was rather stable - no significant differences between two observed depth. However, in the literature there are many examples showing the decrease of TOC fluxes with depth (Nielsen and N,rnberg 1995). The single horizontal lysimeter has a greatest variability for this figure, which indicates that the soil conditions plus longer pathway for seepage water makes it quite unpredictable. 


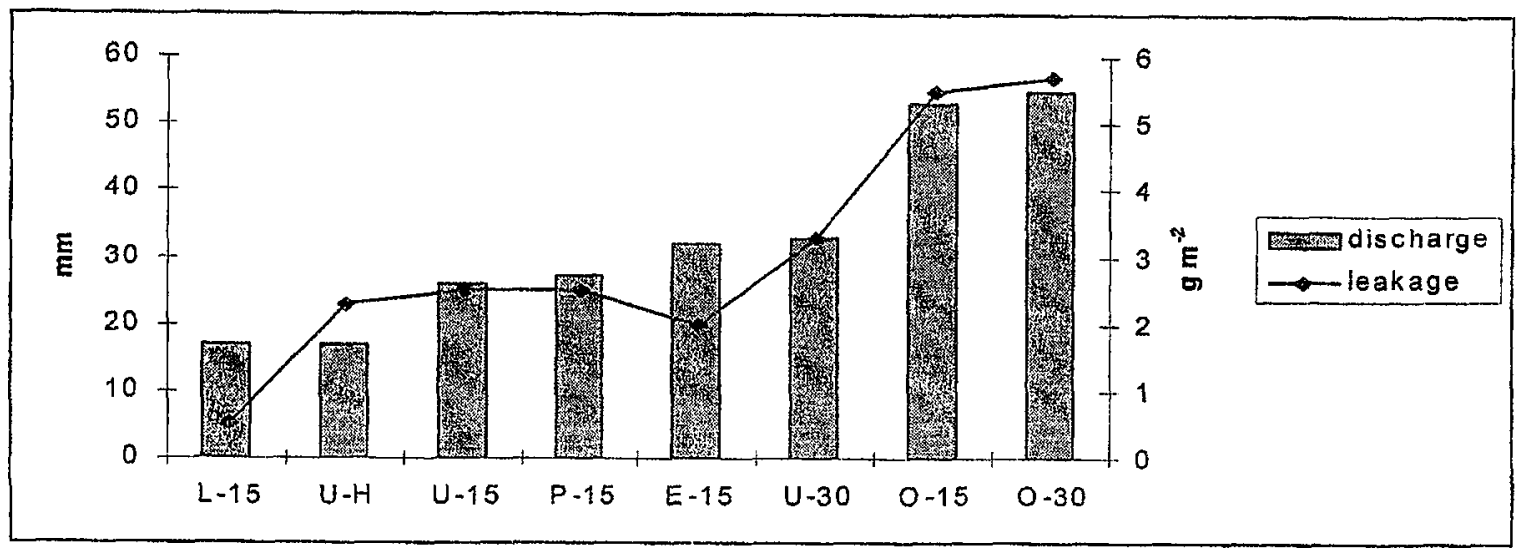

Fig. 3. Relationship between mean carbon leakage and mean lysimeter discharges, 1997.

Fig. 4 illustrates the leaching of TOC calculated in $\mathrm{g} / \mathrm{m}^{2}$. During the summer 1997 (June-Oct, 5 month period) the amount of TOC entering the $E$ horizon ranged from $0,5 \mathrm{~g} / \mathrm{m}^{2}$ in the sandy podzol (P-S) to $5,7 \mathrm{~g} / \mathrm{m}^{2}$ in the humus-rich sandy podzol (P$\mathrm{H})$. Yet the next summer was rainier, the washout of carbon was smaller. The limited period of observations allows us only to list the lysimeters according to their TOCemission capacity. This capacity is formed from two blocks: 1) lysimeter discharge, indicating the water flow through particular test site; 2) concentration of organic matter in subsoil water, indicating the organic matter available for solution.

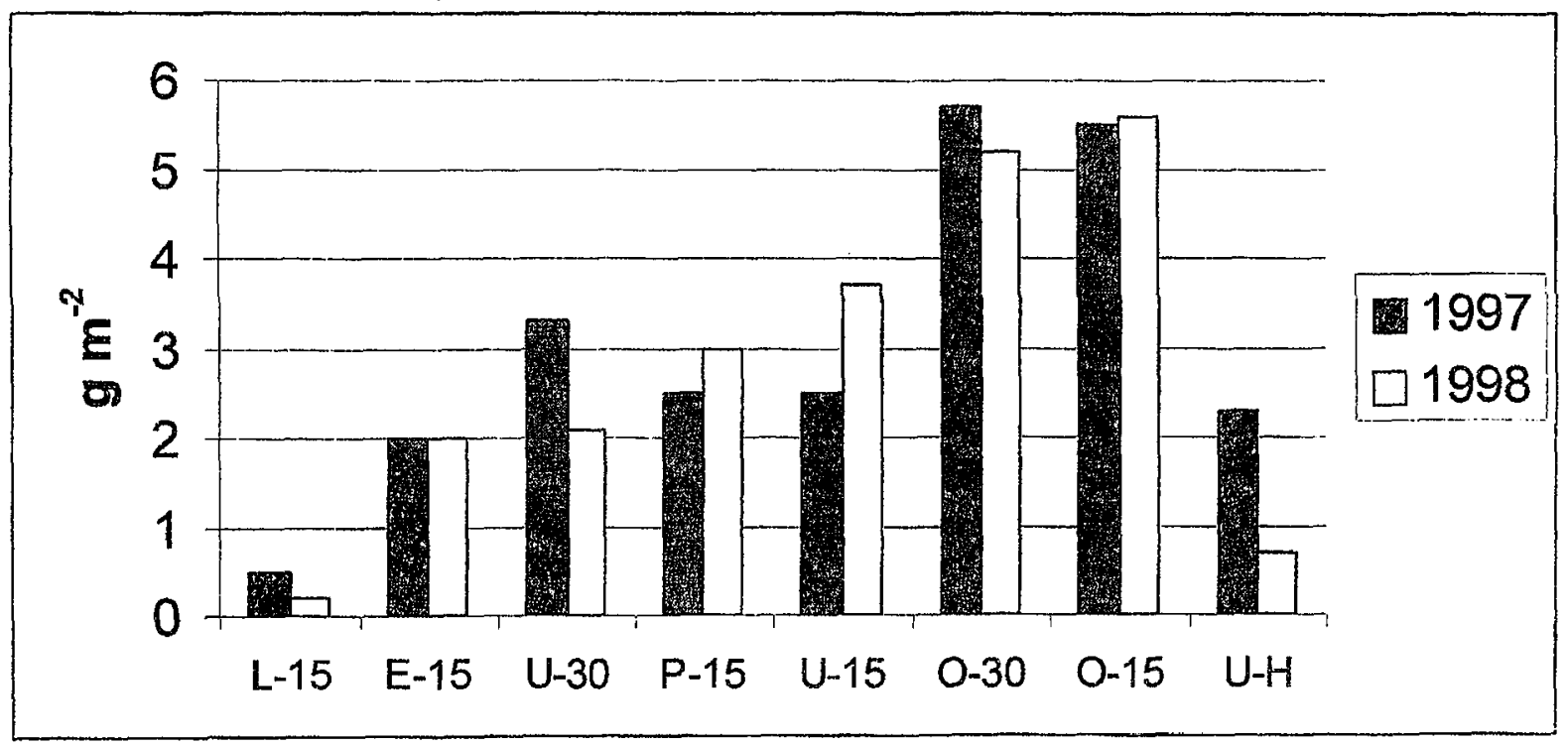

Fig. 4. Leaching of TOC in different lysimeters.

\section{Conclusions}

The washout of organic matter was up to 10 times higher on the humus-rich subsoil waters compared with nutrient poor sands. The highest TOC values were recorded in the transitional depression between esker and sandy plain - in a place where litter fall and erosion products tend to accumulate. 


\title{
REFERENCES
}

NIELSEN K. E., N"RNBERG P., 1995. TOC content as a test of lysimeters in sandy soils in Denmark. Aarhus Geoscience, Vol. 4, pp.39-43.

TÕNISSON A.,1996. Formation of trophic state in lakelets depending on catchment pecularities. Nordic Hydrological Conference, Vol. 2, pp. 579-588.

\section{СРАВНИТЕЛЬНЫЙ АНАЛИЗ СТРУКТУР СЕТЕЙ УВЕРЕННОСТЕЙ}

\author{
О.И.УЖГА - РЕБРОВ \\ Доктор инженерньг наук \\ Резекненская Высшая пкола \\ Атбривошанас ал. 90, Резекне, Латвия, LV - 4600
}

Задачу нахождения общей модели эмпхрических данньгх обычного называют обучением. Предполагается, что в процессе обучения такая модель может быть построена, используя формальньге методы.

Относительно сетей уверенностей задача обучения может быть разделена на две подзадачи: (1) идентификация топологии сети, (2) обучение численным параметрам. Эти подзадачи связаны между собой. Процедуры обучения параметрам в значительной степени зависят от структуры сети.

Основным типом связи на сетях уверенностей является связь «прхчина следствие». События в родительских узлах являются причиной событий в узлах детях. Естественно, что эта связь носит вероятностный характер. Прицина может инициировать некоторое множество следствий с определенными вероятностямх. Причинные модели являются привлекательньми главным образом потому, что они обеспечивают эффективные структуры для представления эмпирических данньгх.

Основой эффективности причинной модели является ее модульная структура. Отличхтельным признаком модульной структуры является зависимость следствий только от обусловливағощих их причин. Модульность структуры в наибольпей степени характерна для древовидных сетей уверенностей. Для таких сетей каждый промежуточный и конечный узел может иметь только одного родителя. Отсюда следует, что любое локальное множество следствий в узле имеет единственное множество прихин, отражаемых событиями родительского узла. Действия других причин из другнх непрямых предшественников экранируются родительским узлом и оказьвают влияние на следствия только опосредствованно. Это является проявлением известного свойства Маркова: будущие события условно независимы от прошлых событий при известном текущем состоянии окружающего мира. Древовидные сети уверенностей обеспечивают не только экранирование влияний в направлении дуг, но и обеспечнвают разделение влияний для узлов, находящихся на одном уровне иерархии. Знание множества непосредственных причин оставляет промежуточный узел сети независимым от других узлов того же уровня иерархии на дереве. Единственным исключением являются узлы - дети рассматриваемого узла. Но обратное влияние от узлов - детей на родительский узел возникает только в случае реализации одного или нескольких событий в этих узлах. Степень 